\title{
APHRODITE IN PROCLUS' THEOLOGY
}

\author{
Tuomo Lankila, University of Helsinki (Tuomo.Lankila@helsinki.fi)
}

\begin{abstract}
The outlines of Proclus' metaphysical system are fairly well known. However, the role of the particular deities in this structure is not thoroughly examined. This article deals with the place of Aphrodite within Proclus' theology. Aphrodite has a prominent place in Proclus' thought because devotion to her had long been under moralistic attack and Proclus carried out his defence in the context of Christian intolerance. With Neoplatonic theories of the divine series and henadology Proclus can determine different modes of the Aphrodisiac presence at all levels of reality. The tales which speak about the goddess and the meaning of the rituals dedicated to her are properly interpreted according to Proclus as symbols revealing and adoring the immaculate holiness of life.
\end{abstract}

\section{Introduction}

"The God is one, the gods are many". ${ }^{1}$ These words of Proclus (412-485) sound like an answer directed, two hundred years in advance, at Muhammad, the prophet of consistent monotheism. Proclus' thought is a powerful synthesis of coherent philosophical monism with polytheistic theology. Anyone who ignores him would lose important evidence about how ancient religion was reflected by one of its systematically thinking insiders. Proclus' achievement can be seen as a highly sophisticated formulation of the genuine self-understanding of a threatened, but living religion.

"This is how Aphrodite is revealed; as the most uniform and purest life", is what Proclus ultimately tells us about Aphrodite. Has he turned the sweet goddess of Homer into an abstract concept of obscure metaphysics? Definitely not. If one has the patience to listen to what Proclus has to say, one will be surprised to find

\footnotetext{
${ }^{1}$ Proclus, Theologia Platonica. 3.14, 4, ed. Henri Dominique Saffrey and Leendert Gerrit Westerink, Proclus. Théologie platonicienne, vols. 1-6 (Paris, 1968-1997).

${ }^{2}$ In Platonis Cratylum commentaria 183, 53, ed. Giorgio Pasquali (Leipzig, 1908). 
many notions similar to those that modern research has discovered. Aphrodite is not primarily a goddess of tender love, she is much more. In the first place she is a goddess of reproduction and sexual desires. For ancient worshippers she was not a person to be adored, but a manifestation of a force inherent in the world. All these themes are present in the Proclean theology of Aphrodite. What is peculiar to Proclus is that he tied these issues together within a Neoplatonic interpretative context composed of the doctrines of divine series and henadology, the theory of the unfolding One.

This essay aims at reconstructing the outlines of Proclus' theology of Aphrodite. First I will address a number of passages concerning Aphrodite in Proclus' works, their role, and how this evidence should be approached. Second, I will deal with the historical context of Proclus' intellectual endeavour, his concept of divinity and his theory of the classes of the gods to the extent necessary for the specific topic of this study. Lastly, the material will be laid out in the order suggested by Proclus' theory of divine hierarchy beginning from below, with Aphrodite as a terrestrial demon and proceeding to the goddess' higher manifestations, and the interpretation of her as a hypercosmic deity.

The sources of the theology of Aphrodite in Proclus

We do not have any systematic treatise by Proclus on Aphrodite, although he seems to have had the intention of writing one. In the preface to his main work, Platonic Theology, he promises to give an exposition of Plato's general theory of the gods, an enumeration of all the classes of the gods and then to discuss particular divinities celebrated in the passages of Plato's writings. ${ }^{3}$ The last part does not exist in extant form in the Platonic Theology. Nor is the penultimate section written according to the prescribed design, as the work ends abruptly with the discussion of the hypercosmic-encosmic order of gods. All attempts to reconstruct the Proclean theory of the cosmic and sublunar deities are therefore based on this fragmentary evidence and other works. ${ }^{4}$

The closest one comes to a Proclean work on Aphrodite is the fifteenth treatise of the Commentary on the Republic, where Proclus interprets the famous love affair between Aphrodite and Ares. In Chapter 183, of his Commentary on the Cratylus, he also deals with the etymology of the goddess' name. In the first case the larger context is the problem of poetry as a mode for the expression of the divine truth and a parallel to the Platonic philosophy and in the latter case in the theory of language and the accuracy of names. In the case of Aphrodite, Proclus develops his views especially through the exegesis of Orphism and of Homer. In Proclus' view these sources are complementary: Orpheus relates mainly the goddess' higher forms,

\footnotetext{
${ }^{3}$ Theol. Plat. 1.9, 8-19.

${ }^{4}$ I will, however, exclude from consideration the Chrestomathy for its dubious authorship and also the Hypotyposis which could be regarded as a purely astronomical work.
} 
while Homer deals with her primarily as a cosmic deity. Proclus' hymns offer examples of what gifts should be asked for from the individual divinities. These hymns are composed according to a stable pattern; they begin with an invocation, then enumerate attributes and powers of the god being appealed to, and at the end request something that is appropriate to this deity. ${ }^{5}$ Two of the surviving hymns of Proclus are dedicated to Aphrodite. The first hymn celebrates the whole "foamborn" series, beginning from the goddess of the cosmic level and praising her as

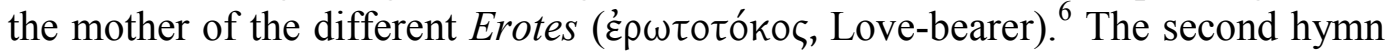
worships her as a Lycian goddess, referring to Proclus' native country. In both of these hymns Proclus asks Aphrodite for freedom from unholy, earth-bound desires.

The historical and theoretical context of Proclean theology of Aphrodite

Proclus was committed to defending traditional religion, whose living space was gradually restricted, as Christianity strengthened its hold as the official ideology of the Early Byzantine state. In his time Neoplatonist philosophy had to act not only in the role of the theoretical defender of the polytheistic cults but also as a substitute for them. ${ }^{7}$ Proclus regarded the "great confusion" in religion (his euphemism for the situation which resulted in the dominance of Christianity) as destined to fade away, although not in the foreseeable future. ${ }^{8}$

This context explains why the "correct" Platonic interpretation of myths was so important to him. Proclus thought that any interpretation of the gods that remained on the surface level, where gods were depicted as active anthropomorphic beings and their doings appeared morally questionable, would undermine the foundations of true religion and provide the Christians with weapons to attack it. ${ }^{9}$ His radical

\footnotetext{
${ }^{5}$ M. L. West, "The Eighth Homeric Hymn and Proclus," The Classical Quarterly 20 (1970), pp. 300-304; H. D. Saffrey, "From Iamblichus to Proclus," in Arthur Hilary Armstrong (ed.) Classical Mediterranean Spirituality (London, 1986), pp. 250-65.

${ }^{6}$ Procli hymni. 2, 1 1, 13, ed. Ernst Vogt (Wiesbaden, 1957). It would be tempting to think that with this epithet Proclus is intentionally echoing and developing a parallel to the evolving Christian doctrine of Mary.

${ }^{7}$ Proclus explicitly says so in praising his teacher Syrianus, in Proclus, In Platonis Parmenidem 618, 9-13, ed. Victor Cousin, vol. 3, (Paris, 1864, repr. Hildesheim, 1961).

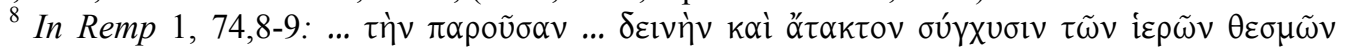
(horrible disorder in religion under present conditions). The same word with the same intention is used also In Parm. 954,1-2 and Proclus, Procli Diadochi in Platonis Timaeum commentaria, ed. Ernst Diehl (Leipzig, 1903-1906) 3.44, 6. See the list of the expressions referring to Christianity in the works of Proclus and Marinus in Saffrey, "Allusions anti-chrétiennes chez Proclus, le diadoque platonicien,” Revue des Sciences philosophiques et théologiques 59 (1975), pp. 553-63.

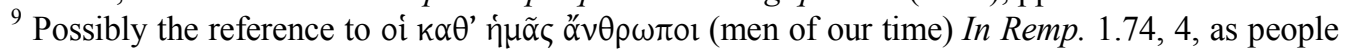
who attribute this responsibility to the ancient myths, does not mean Christians as André-Jean Festugière thought, (in Proclus, Commentaire sur la République I (Paris, 1970), p. 92, n. 1). It may rather refer to pagan intellectuals, who were seeking causes for the ascendancy of the new religion,
} 
thesis was that myth, which is most incompatible with conventional notions of justice and decency could refer through symbols to the highest divine principles. With the help of proper exegesis one can ascend from the scandalous layer of mythology, find hidden truths and forge a genuinely pure cult of the gods. ${ }^{10}$

Proclus, for whom the ideal philosopher should be "a hierophant of the whole world", "tries to find a place for different modes of seeing divinity within a framework built on a Neoplatonic view on reality articulated in levels, grades, and degrees.

\section{Science of divine unities as a basis of piety}

Neoplatonism identifies theology with henology, the doctrine of the One. The One is good and the Good is the God. Divinity is the same thing as unity, unification means deification, and divinity is the guarantor, origin and source of essence for all being. ${ }^{12}$ In the strict sense the gods are for Proclus only the One and its participated classes in the primal being; these are the so-called "self-perfect henads (unities)" ${ }^{13}$ Unity is present on all levels of reality, however, down to the edge of

and against whose opinion Proclus wanted to rehabilitate mythology with allegorical and symbolic exegesis.

${ }^{10}$ Regarding the theological myths in Homer, Hesiod and Orpheus see the sixth treatises in In

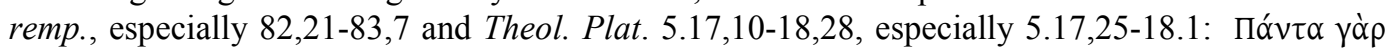

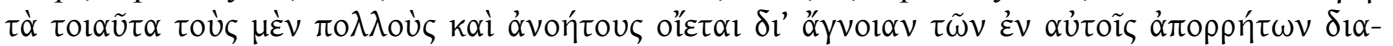

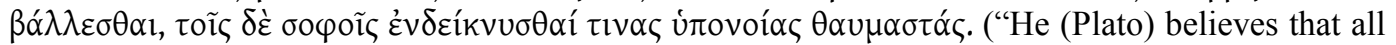
(myths) of this kind deceive the ignorant multitude incapable to grasp secrets in them, while they suggest to wise people admirable hidden meanings.") In the scholarly literature these issues are well discussed by e.g. Jean Trouillard, La Mystagogie de Proclos (Paris, 1982). On the Proclean interpretation of mythology see, for example, James A. Coulter, The Literary Microcosm (Leiden, 1976); Anne D.R. Sheppard, Studies on the 5th and 6th Essays of Proclus' Commentary on the Republic (Göttingen, 1980); Robert Lamberton, Homer the Theologian (Berkeley, 1986); Oiva Kuisma, Proclus' Defence of Homer (Helsinki, 1996). Important contributions which also deal with, among other themes, the problem of Aphrodite in Proclus are Michael Erler, "Interpretieren als Gottesdienst," in Gilbert Boss and Gerhard Seel, Proclus et son influence (Zürich, 1987), pp. 180-217; Robbert M. van den Berg Proclus' Hymns (Leiden, 2001); and Robbert M. van den Berg Proclus' Commentary on the Cratylus in Context (Leiden, 2008).

${ }^{11}$ Marinus, Vita Procli sive de felicitate 19, ed. R. Masullo (Naples, 1985).

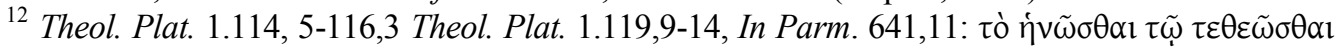

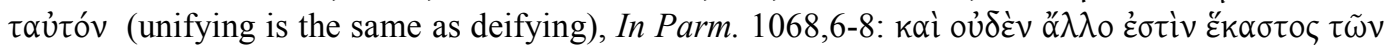

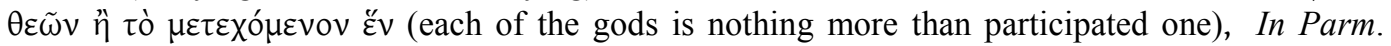

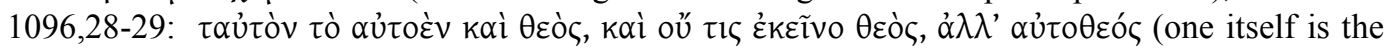
same as god, and it is not any of the gods, but the God itself).

${ }^{13}$ Pursuing absolute purity of transcendence in the first principle, Proclus posits the absolutely imparticipable One and a derived class of the primordial unities (henads) which open themselves for participation by beings. Independent henads are supraessential unities participated in by the root members (imparticipable monads) of the ontological series (such as chains of beings, lives, intellects, and souls). The derived henads presents unity in the secondary members of these classes of being (from a participated monad to the last member of the respective class) and also in the 
pure matter, and in this sense the Neoplatonists accept the Presocratic dictum that everything is full of gods. ${ }^{14}$ The gods of Olympus find their place in the Proclean hierarchy far below the self-perfected henads, but even they, Aphrodite among them, are certain manifestations of unity.

Thus the same divinity known by a certain mythological name could be present and is necessarily present on different levels of reality. ${ }^{15}$ Modern research on the Neoplatonist hierarchy of the gods has located Plato's lower Aphrodite on the level of hypercosmic-encosmic gods. Luc Brisson, for example, finds her exactly in the second term of the fourth triad of the dodecad formed by the hypercosmic-encosmic deities. ${ }^{16}$ It is more difficult to situate the first Aphrodite however. ${ }^{17}$

At every level the task of the gods qua gods is to generate, to produce and to exercise providence towards the universe. ${ }^{18}$ Human beings interact with this providential activity through religious cult and prayer. For Proclus ideal prayer presupposes precise knowledge of all the classes of gods. ${ }^{19}$ We can see a model of this kind of prayer in the prefaces of Proclus' main works, which Proclus habitually opens with a prayer. At the beginning of the Commentary on Parmenides he asks for appropriate help from each divine class for the reception of the mystical vision of Plato. ${ }^{20}$ However, to understand this correctly: The One and the highest henads are not receivers of prayers linked with human language. These highest divinities should be worshiped only transcending intellect in silence and by the unification prior to silence. ${ }^{21}$

things of the world of becoming, mediating for them the illumination of oneness. The supraessential henads are the gods, whereas the illumination of oneness is a god in each thing and the highest summit of its existence. This theory is exposed in Proclus, Elements of Theology, ed. Eric R. Dodds (Oxford, 1963), propositions 2, 6, 64, and 113-162 and the third book of Platonic Theology. For modern research on the topic see especially the first chapter in the introduction to the latter work, Saffrey and Westerink, Théologie platonicienne 3 (Paris, 1978), pp. ix-lxxxvii; Christian Guérard, "La théorie des hénades et la mystique de Proclos," Dionysius 6 (1982) 73-82, and P.A. Meijer, "Participation in henads and monads in Proclus' Theologia Platonica III, chs, 1-6," in E.P. Bos and P. A. Meijer, On Proclus and His Influence in Medieval Philosophy (Leiden, 1992), pp. 65-88.

${ }^{14}$ Proclus refers explicitly to this dictum in De sacrificio et magia 149, 26 ed. Joseph. Bidez, Catalogue des manuscrits alchimiques grecs 6 (Brussels, 1928).

${ }^{15}$ For clear example of how to understand different stages of the series (here the series of Apollo) see In Remp. 1.147,6-15.

${ }^{16}$ Luc Brisson, "Proclus et l'Orphisme," in his Orphée et l'Orphisme dans l'Antiquité grécoromaine (Aldershot, 1995), p. V.86 and How Philosophers Saved Myths (Chicago, 2004), p. 98.

${ }^{17}$ I will not try to expound here the whole structure of Proclus' divine world. Relevant levels for the location of Aphrodite can be seen in the appended table. For a more synoptic view see the appendices in Brian Duvick, Proclus, On Plato Cratylus (London, 2007), pp. 173-75, and Hans Lewy, Chaldaean Oracles and Theurgy (Paris, 1978), pp. 483-85.

${ }^{18}$ Theol. Plat. 5.108, 3, ET prop. 120.

${ }^{19}$ In Tim. 1.209,9-11.

${ }^{20}$ Proclus, In Parm. 617. Both the In Parm. and Theol. Plat. begins with a prayer to the gods and praising Proclus' teacher Syrianus.

${ }^{21}$ Theol. Plat. 3.30,4-8. 


\section{Demonic Aphrodite}

In his Commentary on the Republic Proclus gives an exegesis of the Judgment of Paris. ${ }^{22} \mathrm{He}$ uses the alternative mythological name for Paris, Alexander, and sometimes speaks only of the "barbarian". His interpretation has both a demonological and psychological interest. In his view the sheer idea of a real quarrel between the goddesses is monstrous and should be rejected. There has never been a verdict of a mortal barbarian on the goddesses. His explanation for the human perceptions of divine visions is that they concern lower links in the divine chains and that the gods reveal themselves to the soul's internal faculty of fantasy, which has its material part in the so-called pneumatic vehicle of the soul. ${ }^{23}$ Denying the historicity of Paris' judgment Proclus in this particular case avoids taking a stance concerning the reality of divine epiphanies. As far as he is concerned the mythologists have here represented relationships outside space and time as an event in mythological history.

The core of Paris' story in Proclus is psychological. Proclus' exegesis is based on the doctrine of the modes of the soul's life as found in Plato's Phaedrus. When coming into the world souls choose, under divine supervision, a form of life that corresponds to their dispositions. A kingly life is dependent on Hera, a philosophical one on Zeus (represented by Athena in the tale of Paris), a loving one on Aphrodite.

Proclus' description of Paris' choice is typically Platonist: A blind soul cannot recognize its own good. Paris' choice therefore is "careless, a throwing of oneself on sensible beauty and pursuing the idol of intelligible beauty." 24 If he had been in Paris' position, Proclus would of course have given the prize to Athena. This would have been the philosopher's solution and especially appropriate to Proclus who has a special relation to this goddess. ${ }^{25}$

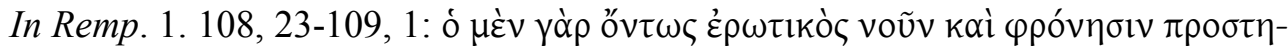

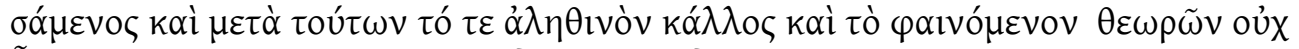

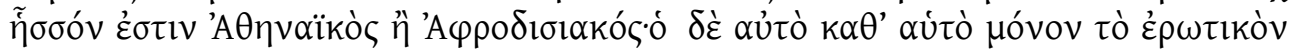

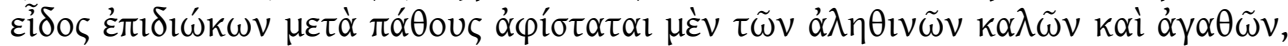

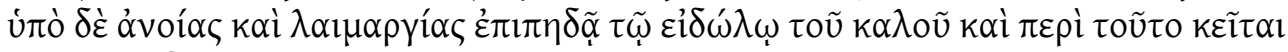

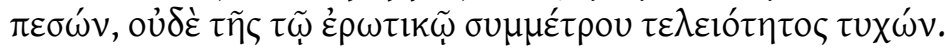

An authentic eroticism, with has taken understanding and wisdom to be its guides, and can distinguish with aid of these between real and apparent beauty, does not belong less to Athena than Aphrodite ... But he who pursues exclusively and passionately only the life of love draws himself away from the really beautiful and

\footnotetext{
${ }^{22}$ In Remp. 1.108, 1-109, 7.

${ }^{23}$ For the theory of epiphany see In Remp. 1. 39, 1-40, 3.

${ }^{24}$ In Remp. 1. 108, 20-22.

${ }^{25}$ Marinus tells us that Athena moved to live with Proclus after her statue was removed from the Parthenon, Marinus, Vita Procli 30, see also 6,9 ,15, and 29.
} 
good, and with the desire and trust of the glutton grasps at the idol of beauty and remains joined to the fall without accessing the perfection appropriate to the real eroticism (translation mine).

Proclus does not condemn the pursuit of earthly love as such. Neither should his thoughts regarding the contrast between the goddesses be interpreted in a manner that would equate Aphrodite with an amorous life driven by passion. But the goddess is not only these aspects, especially contemplated as a leading deity in her own divine series. The real erotic summit belongs to Aphrodite:

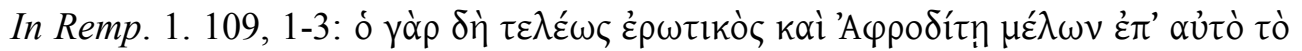

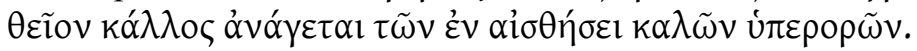

...because a perfectly erotic being, who is taken care of by Aphrodite, ascends towards divine beauty itself, despising the beautiful things on the level of the sensible (translation mine).

Proclus thus links Aphrodite with the authentic erotic madness which functions as a springboard for the soul's purification. ${ }^{26}$ However, Aphrodite's series also provides for those beauties that are perceptible on the corporeal and material levels.

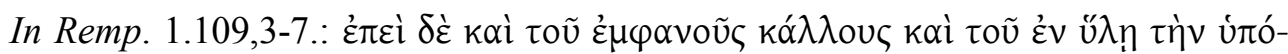

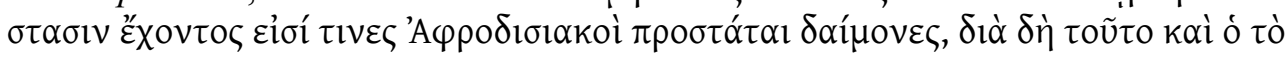

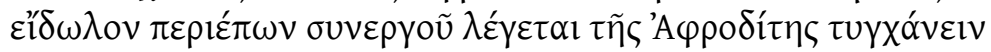

At the same time there exists certain aphrodisiac demons who supervise apparent beauty and that which is seen in matter and, because of that, it is said that such a person who respects an idol has gained the help of Aphrodite (translation mine).

In the Commentary on the Republic Proclus discusses divine possession in connection with Aphrodite. ${ }^{27}$ He cites with evident approval the argument of his predecessor, the Neoplatonist Theodore of Asine, that divine possession could also happen to women. Theodore's example is Helen of Sparta. Aphrodite filled Helen with graces regarding her soul and body to such an extent that Helen was born to be like a new Aphrodite, who coming from the sky, cheated the barbarian (i.e., Paris) into thinking that he possessed something that he did not in reality. Helen with whom Paris lived was not real but some kind of idol. The Egyptians among whom Helen lived taking part in the holy rituals have kept in their memory an authentic image of Helen, but among the Greeks "men of the theater" slandered

\footnotetext{
${ }^{26}$ On this salvific role of love see also, for example, De sacrificio et magia 148, 1-3; Theol. Plat. 1.113,.4-10.

${ }^{27}$ In Remp. 1 254,29-255,28. 
her with stories that have no true basis. Proclus does not openly express himself in favour of Helen's holiness. The context in which he discusses the question is the traditional Platonist defence of the identity of the virtues of men and women. The story narrated by the philosopher of Asine offers one argument more to Proclus in this task. However it is clear that Proclus' resorting to this argument shows that he believed in the possibility of real divine possession.

In the Commentary on the Cratylus ${ }^{28}$ Proclus expresses precise opinions on the theory of divine series, how demons acting in the material world should be seen as the extremities of these divine series. In his view terrestrial spirits and particular demons participate in the divine demiurgy as co-producers of beings of the sensible world The myth-makers use the same names to refer both to the leaders of the series and to the lower spirits. Proclus thinks that the very last members of the divine series can in fact have intercourse with humans and thus generate heroes. This is not surprising as the lowest demons are sympathetic not only to humans, but also to other species of living beings, and this is why we have cases of nymphs joining to trees, wells, deer and snakes.

Proclus connects the question about the relation between Aphrodite and Eros to the relations of the (celestial) gods and demons. He reminds us that Plato calls Eros a demon in the Symposium, saying that he is a companion of Aphrodite, and originates from Poros, who is a real god, whereas in the Phaedrus Plato calls Eros himself a god, because he is an uplifting life force. ${ }^{29}$ Thus the case of Eros also shows that the demons are companions and followers of the gods. But this is not the whole truth of the relationship between Eros and Aphrodite, as we will see in the treatment of the gods on the higher levels of the hierarchy.

\section{Cosmic Aphrodite}

Proclus' consideration of Aphrodite as a cosmic deity includes purely astronomical issues, but also such which are relevant for theology. Aphrodite and Hermes are sunny stars, because they help the Sun in its creative action and collaborate with it in order for all things to fulfil their destiny. As a cosmic monad the Sun is "miraculous, unsurpassable, a disproportionate power in itself and with all others.",30 We see here the Sun's relation to the visible world matching the relation of the demiurge to the cosmos, and this again mirrors the relation of the One to reality. Aphrodite and Hermes present themselves as inseparable companions of Helios in the cosmic demiurgy. They set their own movement in harmony with the creative act of this star. They bring proportion and symmetry and a happy mixing to all things. ${ }^{31}$ Aphrodite and Hermes depart and approach the Sun as his bodyguards. ${ }^{32}$

\footnotetext{
${ }^{28}$ In Crat. 118,1-26.

${ }^{29}$ In Tim. 3.154,27-30.

${ }^{30}$ In Tim. 3. 65,30-66,2.

${ }^{31}$ In Tim. 3.66,2-5.
} 
Both Hermes and Aphrodite are unifying principles in the world according to Proclus, Hermes "takes part in the making of the daily and nightly phenomena and masculinizes and feminizes itself," while Aphrodite participates in the creative acts of the solar monad "for she has the ability to bind and adjust that which has been separated." 33

Proclus says that Aphrodite unifies and leads Hermes' and Helios' actions to a communion, and gives harmony to that which is in the one careless ( $\alpha v \varepsilon 1 \mu \varepsilon ́ v \eta v)$

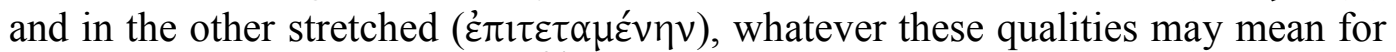
Hermes' and Helios' demiurgy. ${ }^{34}$ Proclus describes Sun's celestial companions as a cosmic image of the noetic triad:

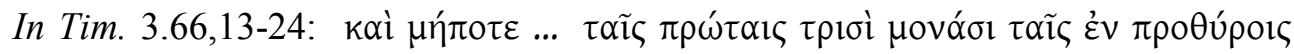

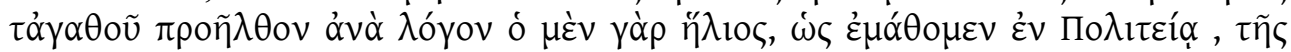

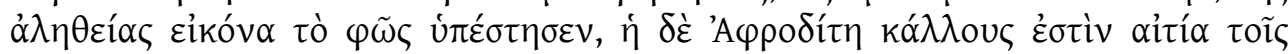

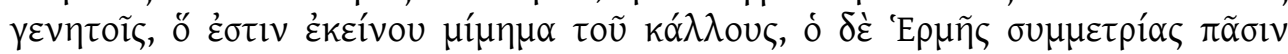

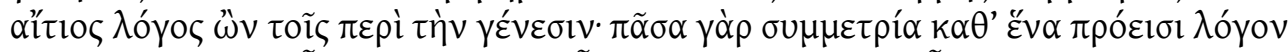

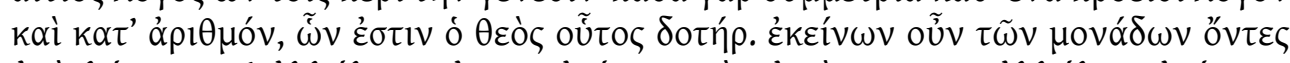

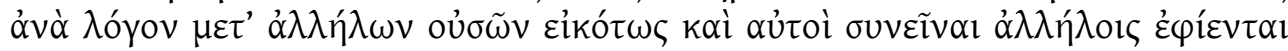

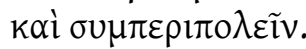

Perhaps these stars have appeared into the cosmos in analogy with the first three monads ... these monads we find at the vestibule of the good (a reference is to Plato's Philebus 64c). ${ }^{35}$ And indeed, as we have learned from the Republic (VI 508b12) the sun produces the light as a likeness of truth, and Aphrodite is the cause of beauty for the beings in cosmos and the copy of the beautiful beings in the noetic triad. Calculating Hermes is the cause of proportion for all beings in the world of becoming ... Like the sun, Aphrodite and Hermes are also analogous to these mutually unified monads and because of this they also want with justice to come together and create their cycle in concert (translation mine).

Since Proclus returns to the analogy of the cosmic world and intelligible triads in other passages, ${ }^{36}$ it is clear that the correspondence is not for him a casual result of exegetic zeal.

In this same place in the Commentary on the Timaeus, ${ }^{37}$ where the main issue to be dealt with is the world's body, Proclus explains that the planetary deities are

\footnotetext{
${ }^{32}$ In Remp. 2.59,1.

${ }^{33}$ In Tim. 3.65,5-8. Aphrodite was represented in some statues also with beard; cf. William Sale, "Aphrodite in the Theogony," Transcations and Proceedings of the American Philological Association 92 (1961), pp. 508-521. Proclus associates hermaphroditic traits only to Hermes.

${ }^{34}$ In Tim. 3. 67.

${ }^{35}$ It is not quite obvious where Proclus situates the vestibule of the Good. On the grounds of similarities in this passages and Theol.Plat. 3.64,8-12 I am inclined to think that he means the last term of the noetic triad which is characterized by the monads of symmetry, truth and beauty.

${ }^{36}$ In Tim. 3.69, 5-69, 14.

${ }^{37}$ In Tim. 3.69, 15-27.
} 
the causes of the passionate and cognitive powers of humans as far as the subject of consideration is the composite of body and soul and the soul's two lower, i. e. irrational, parts (the powers of the rational soul naturally depend on a higher place in the divine hierarchy). The moon, "the visible image of the source of nature," is the cause of physical growth, the sun produces the totality of the sensations, and Hermes is the cause of the movements of the imagination (of the movements only, Proclus specifies, since "the cause of the fantastic faculty as such is Helios, since sensation and imagination form the same faculty"). Aphrodite produces the lustful desires of the lower irrational soul, Ares the movements of anger, depending on nature. Zeus produces vital powers universally, and Cronus, in the same manner, cognitive powers.

The task of the planetary gods is to join the age period of the human being to the seven divine series. Proclus gives his most detailed description of this issue in his Commentary on Plato's Alcibiades, ${ }^{38}$ in a manner which corresponds, albeit with some strain, to the theory just outlined. "The third (period) is that which belongs to the series of Aphrodite as boys begin to produce sperm and set in motion the natural powers of child-making". The role of Helios in this picture forces Proclus actually to identify the noon of life with the life epoch of a young man, and the agreement with the previously-mentioned theory in the Commentary on the Timaeus is not altogether successful, but unsurprising as far as the exegesis regards Aphrodite.

Once more in the Commentary on the Timaeus Proclus returns to the question of Aphrodite and the desiring soul when he starts to deal with the structure of the human body. ${ }^{39}$ This anatomical exegesis does not advance very far, because the manuscripts break off here. Proclus sets the planetary gods in connection with the human faculties referring to what "someone has said". This expression implies perhaps a slightly reserved attitude to the theory that is expounded. The most interesting trait in this passage is that Proclus places Hermes as a discursive faculty between the thymos of Ares and the epithymetikon of Aphrodite. And how indeed could he do otherwise, seeing that he has to treat the divinities in their natural, planetary, order, going this time from top to bottom, from the sphere of the fixed stars to the level of the moon? He then continues establishing a correspondence between our pneumatic body with the sky and our mortal body with the sublunar world. But neither does this passage have anything surprising to say about Aphrodite.

With respect to the theory of the body of the world, Proclus rejects the doctrine of correspondences between divinities and elements. ${ }^{40}$ In this doctrine, which is Pythagorean according to Proclus, the element of Aphrodite is air. Proclus says that the Pythagoreans have the correct opinions insofar as they regard Aphrodite and Hermes as gathering and unifying divinities. Their doctrine of the elements

\footnotetext{
${ }^{38}$ Proclus, In Platonis Alcibiadem 1.196.2-19 ed. Alain Philippe Segonds, Proclus. Sur le premier Alcibade de Platon (Paris, 1985-1986).

${ }^{39}$ In Tim. 3.354,29-355,20.

${ }^{40}$ In Tim. 2.48,15-49, 12.
} 
differs from the Platonic, which sees all elements as present in each planetary sphere in the same way as the sublunar elements participate in each other.

When it comes to dedicating seasons to divinities, Proclus accepts this theory. ${ }^{41}$ Cronus and Ares, winter and summer, form an opposite pair, while Zeus and Aphrodite, spring and autumn, form another. The connection between Aphrodite and autumn is easy to understand: "... autumn belongs to Aphrodite," Proclus says, "because during this season seed is thrown to earth and the task of Aphrodite is to mix fertile germs and lead them to communion with the cause of becoming."

Proclus sees Aphrodite as a demiurgic power that brings into harmony and unification the masculine and feminine, ideal forms and matter in cosmos. ${ }^{42}$ This is why he also interprets the office for the supervising public marriages in Plato's treatment of the ideal state as being analogous to Aphrodite.

A final Aphrodisiac item of the cosmos belongs to the area of astrology. Each star has special mutual positions which are dangerous to the development of the embryo. If Aphrodite has been in this adverse position during the conception, this destroys the seed at the 120th day of pregnancy. Proclus does not say if he held this opinion, he states it as a rule of the Egyptians. ${ }^{43}$

\section{Aphrodite as a hypercosmic-encosmic deity}

On the next level up, the hypercosmic-encosmic order, Proclus posits a divine dodecad which corresponds to the twelve gods of the Phaedrus.

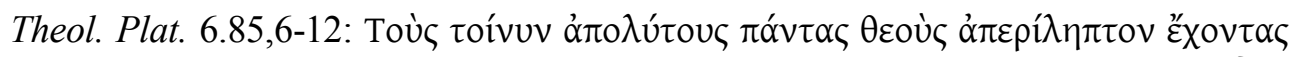

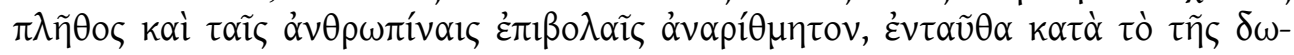

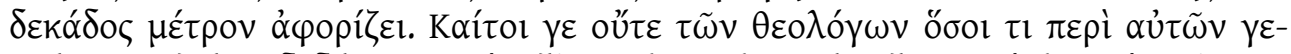

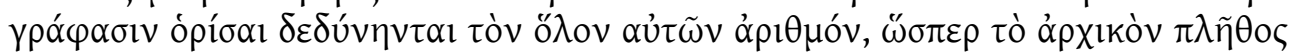

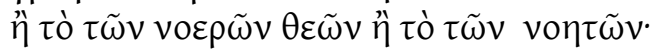

The plurality of these deities is incomprehensible and impossible to enumerate for human intuition but inspired Plato defines them in Phaedrus' vision with the model of a dodecad. None of the theologians, who have written something about them, has been able to define the perfect number of these divinities, as opposed to that plurality which relate to the primordial principles, noeric gods, and noetic gods (translation mine).

With these previous gods Proclus probably means the first henads derived from the One — the limit and the infinite — and the noetic and noetic-noeric triads

\footnotetext{
${ }^{41}$ In Remp. 2.62,6-18.

${ }^{42}$ In Tim. 1.34,15-17.

${ }^{43}$ In Remp. 2.58, 20. See Festugière's note in Proclus. Commentaire sur la République 2 (Paris, 1970), p. 167 n. 1.
} 
mentioned above. Proclus believes that for Plato the number twelve is appropriate to these divinities, which are called "unchained", because the dodecad is wholly perfect, being composed of primordial principles and the most perfect ingredients and covering the entire procession of being with its measure. ${ }^{44}$ This obscure manner of expression refers to the fact that twelve is the result of the multiplication of three by four, the triad being the structure of conversion and perfection and the tetrad the structure of stability and harmony.

Thus twelve divinities are divided into four triads, of which we are interested here only in the properties of the last "uplifting" triad (Hermes, Aphrodite, and Apollo) and the last members of the immediately preceding triads, in other words the gods Hephaestos and Ares, because of the obvious mythological importance of these gods for Aphrodite. Hephaestos' function is to install "nature in bodies and construct the abodes of the cosmic gods." 45

The most universal and first species of life originate in the second and third terms of the uplifting triad (Aphrodite and Apollo) together with the last term of the previous triad (Ares). Souls are installed into their modes of life according to these divinities when they descend to the cosmos.

Souls ascend through the same triad. Philosophy (Hermes), love (Aphrodite), and the cult of the gods (Apollon) recuperate all that was lost in the process of becoming. Aphrodite acts as a primordial cause of loving inspiration, which permeates universally all things and orientates uplifted lives towards primal Beauty (third triad of the first intelligible triad). ${ }^{46}$

This view of the souls' road to salvation is at first glance in accordance with the famous passage of the Platonic Theology often cited as a Proclean "definition" of theurgy. ${ }^{47}$ The highest path of ascent there links the theurgic power, faith and the good, the second salvific channel goes from philosophy through truth to wisdom, and the third from the erotic madness through love to beauty. Hermes and Apollo do not always seem to occupy the same position in the works of Proclus but Aphrodite is similar in both the first and the sixth part of the Platonic Theology.

The fifteenth treatise of Proclus' Commentary on the Republic ${ }^{48}$ is dedicated to the relation of Aphrodite, Ares, and Hephaestos, inquiring into the role of these divinities in cosmogony from the hypercosmic to the sensible order.

Proclus says that Hephaestos and Ares are both acting "towards" the whole of reality. Ares separates the opposing principles of wholeness and saves them as immutable and intact in order that the world should always be fulfilled by all forms. In accordance with his art Hephaestos creates the perceptible world order and fills nature with generative principles and forces. The symbols of these are the celestial tripods mentioned in the Iliad $(18,373)$. The brooches, spiral armlets, cups, and

\footnotetext{
44 Treatise on the twelve gods, Theol. Plat. 6.97,1-99, 21.

45 Theol. Plat. 6.97,16-17.

46 Theol. Plat. 6.98, 18-21.

${ }^{47}$ Theol. Plat. 1.113,4-10.

${ }^{48}$ In Remp. 1.141,1-143,16.
} 
chains mentioned a little bit later in the same song are, for Proclus, symbols of the forms of the sublunar world, which Hephaestos casts.

Both gods need Aphrodite for their deeds, one to bring harmony and order to opposites, the other to bring perceptible beauty and shining clarity to his creation so that this world could be made into the most beautiful of sensible things.

Aphrodite is present everywhere but Hephaestos "participates" to her in the mode of the higher realities. We find in this exegesis four different levels of demiurgy. There are two pairs: where Hephaestos manifests the higher and Ares the lower demiurgy. Hephaestos mode of participation in Aphrodite is hypercosmic and celestial, that of Ares encosmic and sublunar.

Mythology conceals and reveals Hephaestos' mode of action, saying that he takes Aphrodite as his spouse to observe the will of Zeus. Ares' relation to the goddess is called adultery by the myths.

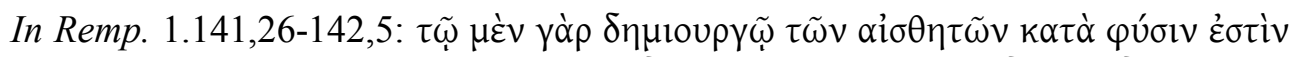

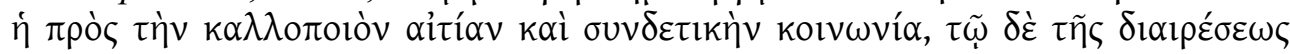

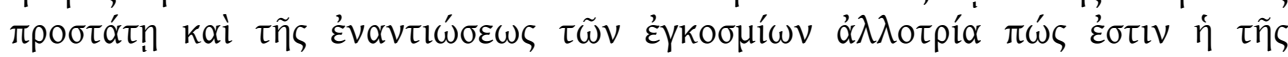

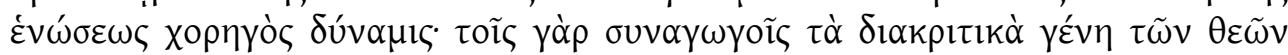

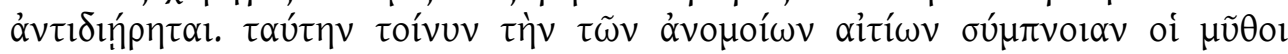

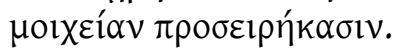

For the maker of sensible things a coupling with the cause which creates beauty and binds things together is natural, whereas for the god, who oversees division and opposition in worldly things, for him the unifying force is somehow alien. The separating classes of the gods are directly opposed to the classes which are unifying. Because of this, the myths call a union of the different causes adulterous (translation mine).

But this kind of union is also necessary for the cosmogony, "in order to bring opposites into harmony and so that the internal war of the world will end into peace." 49

At every level oppositon is the gift of Ares. On the celestial level it refers to the mutual strife between forms when they try to oust each other, while on the terrestrial level it refers to the struggle of the elements and forces. As Helios is the companion of Hephaestos in the production of universal forms, he denounces the intercourse of Ares and Aphrodite to Hephaestos. The chains of Hephaestos, by means of which he captures Ares and Aphrodite, are forces invisible to others and in using them Hephaestos "builds from the opposites of Ares and Aphrodite's joining virtues a unified order, since becoming needs both of them."

Hephaestos' chains are different in the celestial and the sublunar world. The former are indissoluble, while it is possible to loose the latter. Proclus also finds the word "chain" to be a uniting physical force in Plato's Timaeus and this is

\footnotetext{
${ }^{49}$ In Remp. 1.141, 7-142, 7.

${ }^{50}$ In Remp. 1.142,17-19.
} 
enough for him to equate the demiurgy presented in the Timaeus with that of Homer. On the celestial level the demiurge whom Hephaestos obeys is Zeus, but on the cosmic level he chains Ares and Aphrodite paying obedience to Poseidon. Poseidon is the god whose will commands that terrestrial bonds should also be released, because he is the manager of the cycle of change and sees that all which is born will be destroyed and returned to a new beginning.

The demiurge, whether celestial, like Zeus, or cosmic, like Poseidon, builds wholeness with the aid of opposing things and brings friendship to it through proportion, leading the deeds of Hephaestos, Ares, and Aphrodite to communion. Proclus usually favours a method of making divine principles into independent entities, but comes here closer to speaking on particular gods as different aspects of divinity:

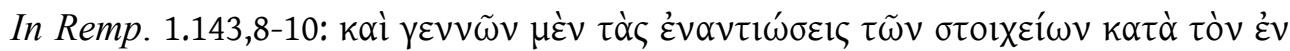

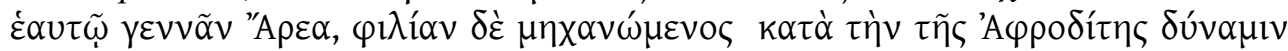

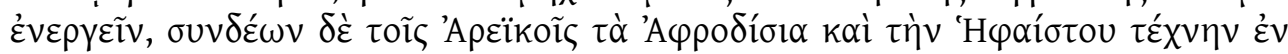
$\pi \alpha \rho \alpha \delta \varepsilon i ́ \gamma \mu \alpha \tau \imath ~ \pi \rho \circ \varepsilon \imath \lambda \eta \varphi \varepsilon ́ v \alpha l$

The demiurge produces opposites from itself according to Ares in himself, he establishes amity, acting on the power of Aphrodite and he joins Aphrodite and Ares because he has beforehand as a preexisting model the art of Hephaestos (translation mine).

The demiurge is all things and acts with all the gods. The gods of the younger demiurgy imitate Zeus but their creations do not have the value of their father's work because their creations are mortal things. In the Commentary on Timaeus Proclus deals with the same passage of the Odyssey, using an allegorical interpretation: “... thanks to this harmony and ( $\alpha v \alpha \lambda$ oyí $\alpha)$ proportion, first of all emerges ( $\tau \alpha u \tau o ́ \tau \eta \varsigma)$ identity and, following it, ( $\left.\varepsilon^{\prime} v \omega \sigma \iota \varsigma\right)$ unification." 51

This exegesis tells us that Hephaestos joins identity and otherness at the higher level, while at the lower level he joins harmony and division. Both of these pairs express communion and oppositeness, which theologians are used to talking about as Aphrodite and Ares. When Apollo, Hermes and the other gods see them in chains, they laugh and this laughter is also a demiurgic act, which, according to Proclus, provides a basis for cosmic things and gives power to their mutual bindings. In Commentary on the Republic Proclus provides a whole treatise dedicated to this divine laughter. ${ }^{52} \mathrm{He}$ explains mythical descriptions of the gods' crying to signify their providence for the corruptible things, whereas the laughter of the gods is described as a mystical sign which refers to their activity on the universal and always in the same manner moving plentifulnesses of the world. ${ }^{53}$

\footnotetext{
${ }^{51}$ In Tim. 2 27, 8-10.

${ }^{52}$ In Remp. 1. 126, 5-128, 4.

${ }^{53}$ In Remp. 1.128, 4-5.
} 
Proclus provides further insights into the role of Aphrodite in the famous battle of the gods described in the Iliad. ${ }^{54}$ War generally functions in tales as an image of cosmic disintegration and strife and this should also be the basis for the allegorical interpretation of this theomachy. The gods are arranged in five opposing pairs. Their disposition follows naturally from the Homeric text and therefore the positions held by Ares, Hephaestos, and Aphrodite depart from those presented in the exegesis of Hephaestos' chains. Only Aphrodite, interestingly, is outside the decad.

Here the pairs of opposites are analogous to the Neoplatonic hypostases of being, life, intellect, and soul, the latter seen as a discursive (Hermes) and an irrational structure (Leto), a sensible and corporal world where Hephaestos is nature, Xanthus the sensible order receiving forms. Aphrodite is below the decad, representing the connection of the whole demiurgy as a principle of harmony. Thus her opposite is the real demiurge, Zeus, who is only implicitely present in this picture. Another interesting feature of Aphrodite in this passage is that Homer, according to Proclus' explanation, sets Aphrodite apart in order for her to illuminate all things with unification and harmony, but especially in order to come to the assistance of the weaker party, because in them plurality dominates unity. ${ }^{55}$ Proclus points out that every opposition is correctly understood only in its connection with unity. But it is interesting that the difference between unity, pre-existing in its cause, and unity as harmony of the parts, is expressed here as a theological relation between the (only implicitely present) Zeus and Aphrodite.

To this aspect refers also the only mentioning of Aphrodite in the Commentary on Parmenides where Proclus says that if we ascend to the gods from the realm of numbers, the hexad is sacred to Aphrodite and the heptad to Athena. "The heptad of Athena is unifying, and Aphrodite's hexad safeguards plurality in company with communion.", 56

Aphrodite as helper of the weak also comes surfaces in those passages of the Commentary on the Republic which complement the Proclean exegesis of the theomachy. ${ }^{57}$ Proclus is here particularly interested in the confrontation between Hephaestos and Xanthus. In physical opposition between bodies Hephaestos represents heat and dryness, Xanthus cold and wetness:

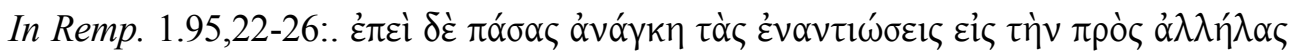

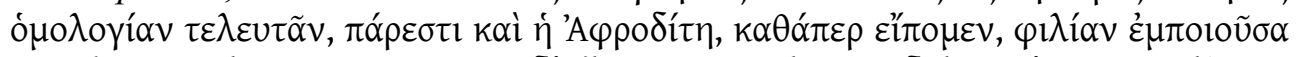

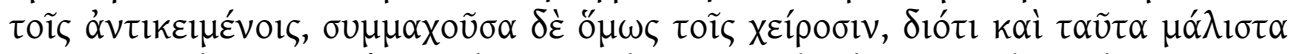

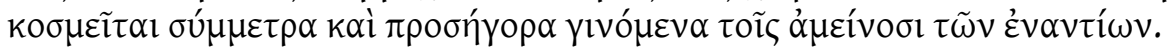

And because every opposition is necessarily destined to end in mutual harmony Aphrodite is also here. Aphrodite establishes amity between the opposites, but she

\footnotetext{
${ }^{54}$ In Tim. 1.78,27-80,5.

${ }^{55}$ In Tim. 1.79.16-19.

${ }^{56}$ In Parm. 768,8. This translation of Morrow and Dillon is from Glenn R. Morrow and John M. Dillon, Proclus. Commentary on Plato's Parmenides (Princeton, 1987).

${ }^{57}$ In Remp. 1.95,18-95,30.
} 
joins herself more to the weaker part, because they above all come to be ordered when they enter into a relation of proportion and reconciliation with the stronger (translation mine).

Thus there is something to be called grace, in the meaning of compassion and generosity, among the blessings of Aphrodite.

Proclus joins Aphrodite to Dionysius, besides Hephaestos and Ares, because she is an encosmic deity. In the Commentary on the Cratylus Proclus says that Plato celebrates Dionysus and Aphrodite as the divinities who are the makers of sweetmindedness, ${ }^{58}$ in opposition to the deities that perfect souls by revenge, fear, and punishment. These delightful divinities are fond of joking and favour it as a means of strengthening weak natures and uplifting difficult corporeal life. For this reason sacral statues represent them as laughing, relaxing, and dancing, in contrast to others whose images are fearful. The cultic representation corresponds to each god's cosmic domain. Aphrodite loves Dionysus and she casts Adonis as an image of Dionysus. ${ }^{59}$ Aphrodite's love for Dionysus is providential, the love of a superior deity for an inferior. ${ }^{60}$

Until now we have been considering Aphrodite among the hypercosmic-encosmic gods in her actions oriented "downward", i.e. as a demiurgic power. Proclus' interpretation of the goddess' magical girdle also concerns the cosmic level, but this symbolism refers to "upwards", to the monads of the goddess' series among the noetic-noeric gods. Proclus here builds his speculations upon the story from the Iliad of the intercourse of Zeus and Hera on Mount Ida. ${ }^{61}$

Proclus explains the significance of all the ornaments of Hera with which she prepares for the event. One of the most important items among them is the girdle borrowed from Aphrodite. Proclus says that these symbols transform Hera into a likeness of Rhea. At the same time Zeus, in falling asleep, renders himself a likeness of the transcendent Cronus. The divinities are no longer functioning at their own level as cosmic deities but are returning to their own transcendental causes:

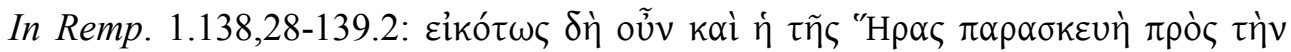

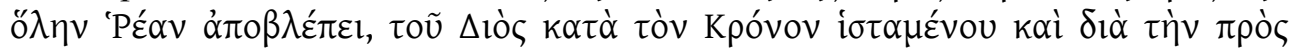

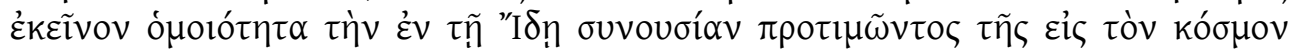

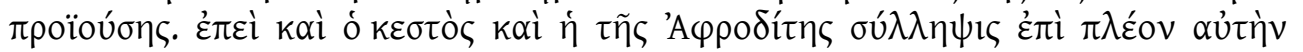

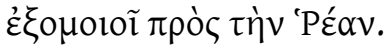

It is quite right that Hera's ornaments resembles the universal Rhea, because Zeus is behaving like Cronus, and because of this similarity (between Zeus and Cronus) Zeus prefers intercourse at Mount Ida to intercourse which goes towards the world.

\footnotetext{
${ }^{58}$ In Crat. $181,15$.

${ }^{59}$ In Crat. 184.

${ }^{60}$ In Crat. 180.

${ }^{61}$ In Remp. 1.138,28-140,18.
} 
At the same way the magical girdle and the aid of Aphrodite renders Hera even more a likeness of Rhea (translation mine).

Here Proclus indicates the highest location at which we can already see Aphrodite as an articulated deity, with a primordial identity, albeit yet without her own name, preexisting in her first cause. In my opinion Proclus is referring to the gods in the second term of the noetic-noeric class. There, according to the words of Proclus,

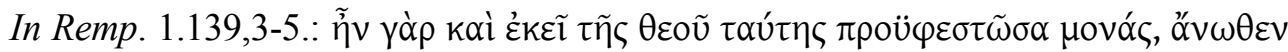

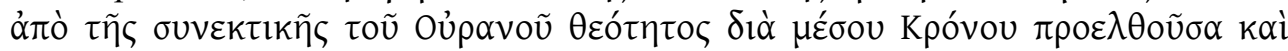

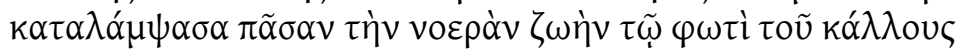

preexists the monad of this goddess who maintains Uranus, who makes her procession through the domain of Cronus and illuminates the whole of intellective life with the light of beauty (translation mine).

Locating Aphrodite's first monad in this level which articulates itself again into subtriads, is consistent as we remember, that the divine love, the first Eros, is the third term of noetic-noeric triad. ${ }^{62}$ If Aphrodite is Erotokos, surely her monad should be on the higher level as the first monad of Eros.

Proclus furthermore analyzes the different ways in which Aphrodite and Hera bear the girdle:

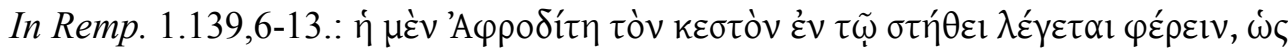

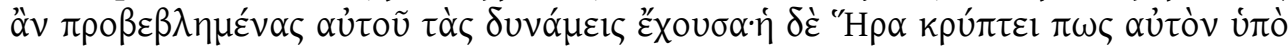

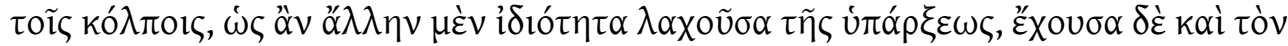

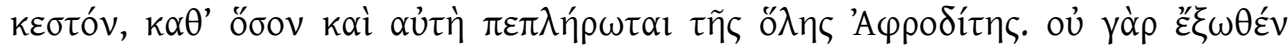

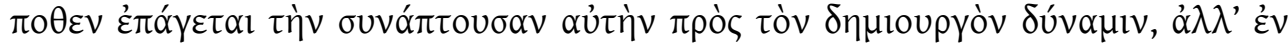

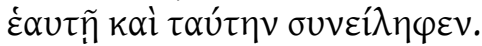

Aphrodite holds it in her bosom in such a manner that she keeps its powers exposed. Hera hides it in her chest, because her mode of existence is different, even if she too has a magical girdle in so far as she is filled with all the qualities of Aphrodite. She does not evoke the power, by which she unites with the demiurge by some external means, but she has enclosed this power in herself (translation mine).

Uneducated but pious common opinions also emphasize the connection between the two goddesses as they respect Hera as mistress of the union of consorts and protectress of marriage. She unites with the demiurge with the aid of the magical girdle, which is in herself, and creates connections in the legitimate bonds of

\footnotetext{
${ }^{62}$ The common monads for all the goddesses' situate themselves higher, on the first level of the

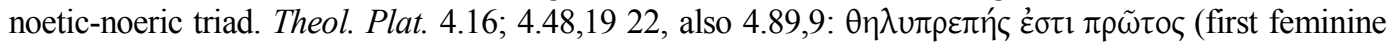

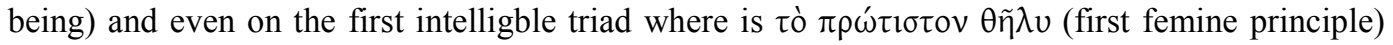

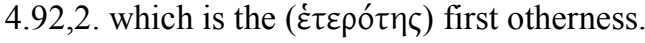


marriage. Apparently Proclus wanted to say that the girdle in Hera is more secret, more linked to the transcendence, and joins to an indissoluble demiurgic union, while with Aphrodite the girdle shows the mode of the demiurgy of the younger gods and is exposed to the cosmos. This is the formulation in the language of the theology of love for the metaphysical principle very common in Proclus stating that every principle has two different mode of existence, ( $\kappa \alpha \theta^{\prime}$ ú $\left.\pi \alpha \rho x l v\right)$ its own, corresponding to its appropriate level, and ( $\left.\kappa \alpha \tau^{\prime} \alpha i \tau^{\prime} \alpha v\right)$ a higher one, where it preexists in its causes. Proclus' language also evokes an image of the more secretive, marital love, appropriate to Hera, as opposed to the other genres, both legitimate and illegitimate, which belongs to the domain of Aphrodite.

\section{Hypercosmic Aphrodite}

The highest level of the theology of Aphrodite is the order where the goddess reveals herself as a hypercosmic deity. On this level Proclus resolves the Platonic question of the "two Aphrodites". In the Platonic Theology Proclus reflects on the subject of what mythological talk about the "births" of the gods means for philosophy. Plato too, he says, speaks with the form of myth on the births of the gods:

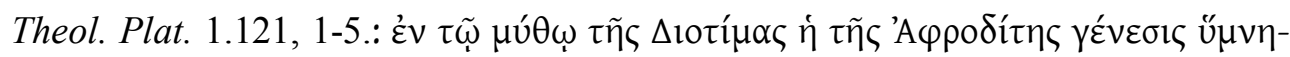

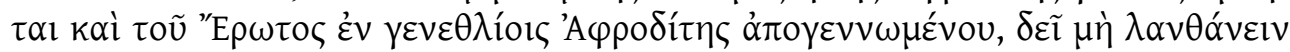

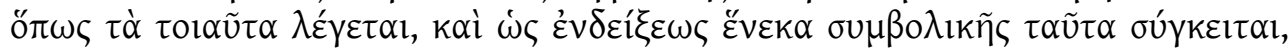

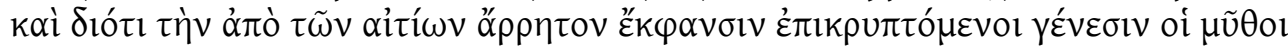

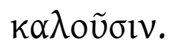

... as, for example, in the myth of Diotima, where Aphrodite's and Eros' births are celebrated ... but it should not be forgotten how these kinds of stories are presented, that they are composed with the aim of symbolic allusion and this is the reason why, hiding the ineffable manifestation proceeding from the primordial causes, myths call it by the word birth (translation mine).

Proclus' opinion is that Plato himself develops such stories when he narrates myths, but his normal way is to use dialectical and intellectual methods describing divine properties with the concepts of science.

In the Commentary on the Cratylus Proclus says that it is also possible to get to be inspired by starting from jokes regarding gods and rising thence to an understanding of realities in a more intellectual manner. ${ }^{63}$ For Plato the difference between the two goddesses was without doubt the distinction between the intelligible world of forms and the sensible level. For Proclus they are hypercosmic and hypercosmic-encosmic divinities.

\footnotetext{
${ }^{63}$ In Crat. 183.
} 
Proclus' handling is a masterpiece of allegorical intepretation of myths. First he states the "materialistic view" on Aphrodite's name:

In Crat. 183, 4-6... 'A

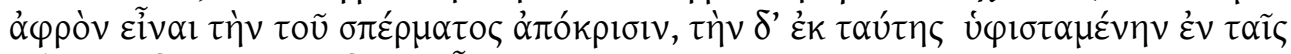

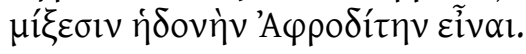

... Aphrodite was born from foam and this foam is the shedding of sperm and pleasure from ejaculation in intercourses is Aphrodite (translation mine).

Proclus does not simply reject this view, it is valid on its own physical level. But as the sensible world is the ultimate phase of the self-expression of the divine powers, behind the physical levels are others and so there is also need for a deeper interpretation which is to see, "before these extreme and corrupt things, the first and eternal causes." Hesiod and divine Orpheus tell the tale of the castration of Uranus. This violent image expresses "inspired notions" of how the goddess was causally produced:

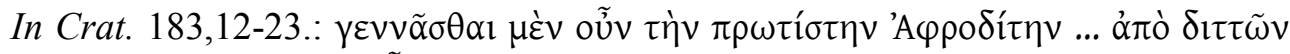

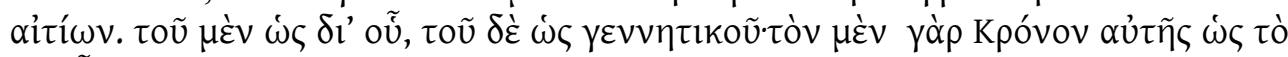

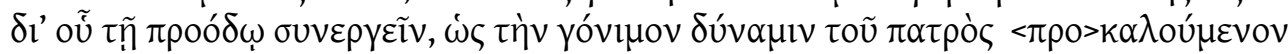

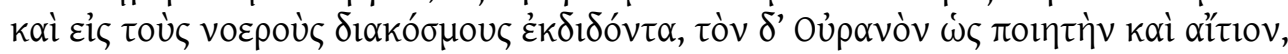

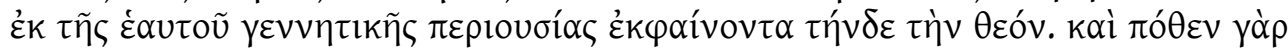

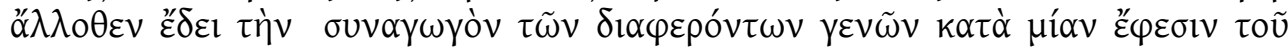

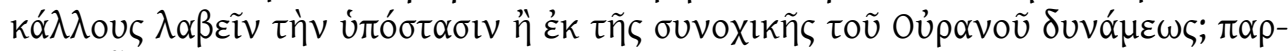

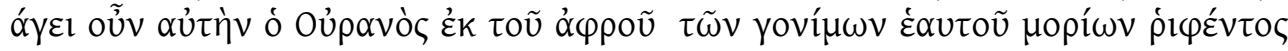

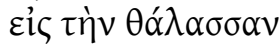

the first Aphrodite was born from two causes: instrumental and generative ones ... Cronus acts as a coordinated cause in her procession; he calls the fertile power of his father and mediates it to the noeric levels, and Uranus is the producer and the cause revealing this goddess starting from his own generative abundance. What other causes does such a hypostasis need, which unify different kinds, acting on the basis of the one and same pursuit of beauty, what other if not the gathering power of Uranus? Thus Uranus generates her from the foam of his fertile organs when they were thrown down into the sea (translation mine).

The procession of the first Aphrodite is replicated in the lower level of sensible demiurgy where "the second Aphrodite flows into being from foam in the same way as the first ...," as, according to Orphic verses "conquered by great desire the lofty father (Zeus) threw foam of semen into the sea."

The two goddesses are different in their causes, order and powers, but their hypostasis - meaning in this passage innermost nature - is the same. Likewise the same is the purpose of their action, which is beauty meaning sound proportion and conformity between any being and its paradigm. The responsibility of the hypercosmic goddess is to secure compatibility between intelligible and sensible forms 
(reason-principles in nature), the responsibility of the cosmic goddess is to participate in the actual demiurgy of the visible world (whose beings are incarnations of these principles). Actualization of the forms in nature is the same as life. Thus the higher goddess is a guardian and distributor of universal, pure, life, the lower goddess of the form of life which is appropriate to each living entity:

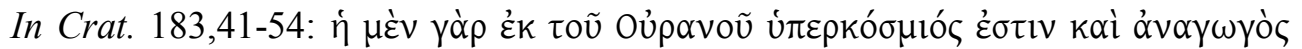

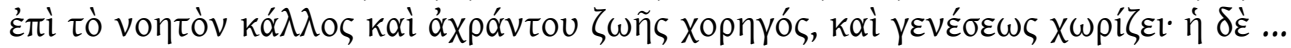

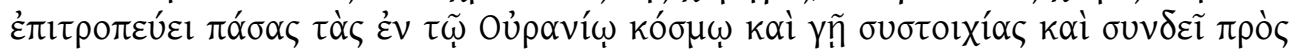

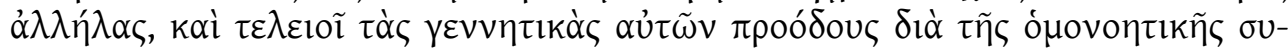

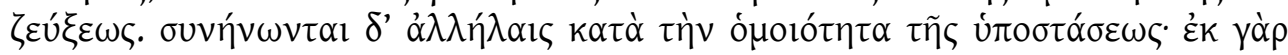

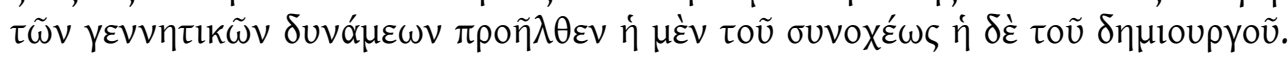

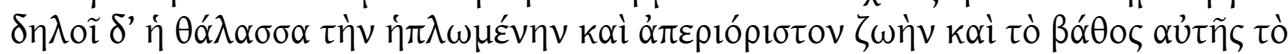

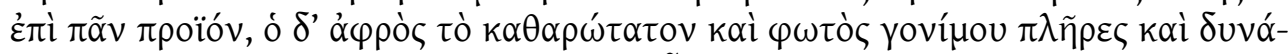

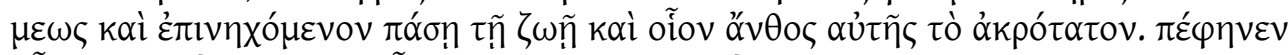

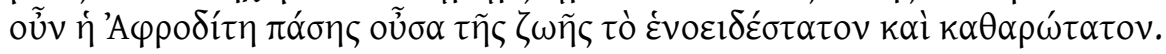

She who is born from Uranus is hypercosmic and aims upwards to the intelligible beauty and is the distributor of the pure life. The other one, ... rules all the connected series which are in the world of Uranus and in the earth, she joins things together and perfects generative processions by unification in harmony. And they are unified among themselves for the similarity of their hypostases, since from the generative powers there proceeds, on the one hand, the gathering power, and on the other, the demiurgic power. And the sea means extended and unlimited life and its depth, which overlaps everything, and the foam signifies the most pure, light-filled, and fertile power and, much more than anything else, it expresses the whole of life and it is, like a flower, its highest summit (translation mine).

Aphrodite gets her name first at the hypercosmic level and Proclus concludes with the description of this goddess. "Flower" and "summit" are quasi-technical terms of later Neoplatonism, meaning highest unification and divinity present in every being. "Flower" is in fact a poetic synonym for "supraessential henad" and the One's mystical sign, which is the highest illumination of oneness in entities enjoying participation in the One through henads. ${ }^{64}$

\section{Conclusion}

Let us summarize the main steps in the procession of Aphrodite according to Proclean theory: On the first level of the noetic-noeric triad, in the supercelestial place, the feminine quality of the divine reveals herself for the first time. In the second term of the noetic-noeric triad exists the depth of the sky, Uranus and his powers,

\footnotetext{
${ }^{64}$ For this doctrine see, for example, In Parm. 1046,2-1047,31; Theol. Plat. 1.15,17-21; In Crat. 47,12-19:
} 
among them the first monad for Rhea and Aphrodite. The third term of the noeticnoeric triad is, in the language of the Phaedrus, the subcelestial vault. The third triad in its totality is love (the first divine Eros) that mirror in its level intelligible beauty (corresponding triad in the intelligible level) and raises ascending souls towards it. The noeric gods are arranged into a hebdomad composed of the two triads and the demiurgic monad. On the first level Rhea manifests herself as an identified deity mediating between Cronus and Zeus. One of the operations of the demiurge is the castration of the previous fathers, which is the symbol for the birth of the internally differentiated world of forms. Through this operation Aphrodite is born as a hypercosmic and hypercosmic-encosmic principle of demiurgy and providence. In her procession, the goddess who pre-exists in her monads on the higher levels, gains an articulated identity and reveals herself as a divinity whose task is to harmonize and recuperate unity. For Proclus Aphrodite is greater than love. Love is the power in life, and Aphrodite is the most uniform and purest life at the hypercosmic level, the Uranic summit in Aphrodite being "the flower of life".

The theory of the divine series enables Proclus to defend Aphrodite in all the forms of her traditional cult against the "great confusion". It is possible to pray to and to celebrate Aphrodite, even from the popular, and even vulgar, viewpoint, as the protectress of earthly love. But a Neoplatonic sage, who has attained Plato's mystical vision, connects the worship of the goddess to the philosopher's aim of identifying with the One present in the human soul, and because of this she or he asks and deserves from the immaculate Erototokos even better gifts than those desired by the Trojan prince. 
Tables

Table 1. Exegesis of the theomachy (In Tim. I,79.1-23, In Remp. 1,95.23-30)

Zeus - the Demiurge

$\begin{array}{lcl}\begin{array}{l}\text { Poseidon } \\ \text { totally }\end{array} & \begin{array}{c}\text { Apollo } \\ \text { particularly }\end{array} & \text { the demiurgy of the whole } \\ \begin{array}{l}\text { Hera } \\ \text { intellect }\end{array} & \begin{array}{c}\text { Artemis } \\ \text { physical }\end{array} & \text { producers of life } \\ \begin{array}{c}\text { Athena } \\ \text { reason }\end{array} & \text { Ares } & \text { causes of opposites } \\ \begin{array}{c}\text { Hermes } \\ \text { cognition }\end{array} & \text { Leto passion } & \text { powers for soul's perfection } \\ \text { understanding } & \text { vitality } & \\ \begin{array}{c}\text { Hephaestos } \\ \text { actively }\end{array} & \text { Will } & \\ & \text { Xanthus } & \text { producers of bodily order }\end{array}$

Aphrodite - giver of unity and harmony

Table 2. Exegesis of the Ares-Aphrodite affair

Two pairs of demiurgy

$\begin{array}{ll}\begin{array}{l}\text { Hephaestos } \\ \text { hypercosmic } \\ \text { insoluble "chains" }\end{array} & \text { Ares } \\ \text { encosmic } \\ \text { releasable "chains" } & \text { sublunar } \\ \text { marriage } & \text { adultery }\end{array}$


Table 3. The divine scope of Aphrodite

Area out of scope (by super-excellence)

One and the Henads

Intelligible gods / noetic triad: goodness, wisdom, beauty

first otherness / first feminine principle

Area of pre-existence

Intelligible-intellective gods / noetic-noeric triad /

First noetic-noeric triad hyperuranios topos / faith

the place of the first feminine quality of the divine

Second noetic-noeric triad / truth

"depth of sky" = place of the first monad for Aphrodite

Third noetic-noeric triad / subcelestial vault /primordial Eros

Noeric gods

noeric triad

separative monad: produces "foam as a flower of life"

Area of existence

Hypercosmic gods: Aphrodite I

Hypercoscmic-encosmic gods

fourth triad, second term: Aphrodite II

Encosmic gods

second triad, second term Aphrodite III

Sublunar "gods" (demons)

Aphrodite as a demon

on the highest level as an Olympian god

on the lowest level as a guardian of certain people

(Julius Caesar for example)

Area of Aphrodisiac illumination

Aphrodite as a power and sign in souls, nature, body, and elements

Out of scope (by privation)

pure matter 